\title{
基于破产模型的新增建设用地指标分解方法 一以湖北省寿阳市为例
}

\author{
左文进 ${ }^{1,2}$, 胡勋锋 ${ }^{3}$, 李登峰 ${ }^{1}$ \\ (1. 福州大学经济与管理学院, 福州 $350108 ; 2$. 上海财经大学浙江学院,金华 321013 ; \\ 3. 广州大学工商管理学院,广州 510006)
}

\begin{abstract}
摘要：传统新增建设用地指标分解方法存在测算指标时视角单一和分解指标时行政力量干预 严重等问题。基于公平和效率的思想引人破产模型, 以湖北朰阳为研究对象, 运用 6 种破产模 型解对其新增建设用地指标进行分解, 并创造性地运用有向图博弯理论对各种分解结果进行 比较分析。研究结果表明: (1) 比例法则和 Piniles 法则符合 “公平优先”主张, 适用于在经济相 对发达的发展阶段和地区应用均衡发展策略; (2) 限制均分损失法则和 Talmud 法则符合“效率 优先”主张, 适用于在经济相对落后的发展阶段和地区应用非均衡发展策略; (3)限制平等法则 和限制均分收益法则适用于有发展条件的贫困地区应用重点扶持的发展策略。新方法不仅有 效规避了传统方法存在的问题,还为发展策略选择提供了多种方案。
\end{abstract}

关键词：破产模型; 有向图博亦; 新增建设用地; 指标分解;麥阳

公平和效率是公共资源分配的基本问题。公共决策中对于公平和效率的不同价值取 向，反映了决策者不同的发展理念。在土地利用总体规划中如何公平且有效地分解新增 建设用地指标，事关地区可持续发展。我国现行新增建设用地指标管理实行 “总量控 制、统一分配、层层分解、指令性管理” 体制，即中央政府控制全国新增建设用地指 标，然后将该指标分解到各省级地方政府，再逐层分解直至乡镇 ${ }^{[1]}$ 。为发挥下级政府的主 观能动性，分配作为公共资源的土地时宜采用 “自下而上” 和 “自上而下” 相结合的方 法，即下级政府应根据本地社会经济发展现状和特征预测规划期内新增建设用地指标并 上报，上级政府则根据一定的原则和方法将其掌控的指标总额分解给各下级政府 ${ }^{[2]}$ 。上 级政府如何合理地分解新增建设用地指标，是衡量土地利用总体规划科学性的关键。

目前，学界对新增建设用地指标分解方法的研究颇为丰富。刘瑞卿等 ${ }^{[3}$ 以主体功能区 划为基础构建指标体系，并计算了卢龙县各乡镇的新增建设用地指标。靳相木等 ${ }^{(4)}$ 将新增 建设用地指标管理与排污权交易进行对比研究, 提出了新增建设用地指标管理的 “配额 一交易” 模型。殷少美等 ${ }^{[5]}$ 运用主成分分析法测算了贵州等地新增建设用地指标。翟腾腾 等 ${ }^{[}$提出一种运用基尼系数分解的方法并与土地利用总体规划纲要中的分解指标进行比较 研究。洪建国等 ${ }^{[7]}$ 运用熵权法以湖北等地为研究对象进行了实证分析。刘耀林等 ${ }^{[8]}$ 从各类

收稿日期：2018-07-07; 修订日期：2018-12-22

基金项目: 浙江省社科规划课题成果（19NDJC396YBM）; 国家自然科学基金重点项目（71231003）

作者简介：左文进（1980- ），男，湖北黄石人，博士研究生，副教授，研究方向为经济管理决策与对策。

E-mail: 123170352@qq.com

通讯作者: 李登峰（1965- ), 男, 广西博白人, 教授, 博士生导师, 研究方向位经济管理决策与对策。 E-mail: lidengfeng@fzu.edu.cn 
公众参与行为的角度运用博亦论分析了土地利用规划决策中用地冲突的解决机制。此 外，在土地利用总体规划编制实践中，下级政府测算需求指标时常用的方法还有层次分 析法、回归分析法、均方差决策法和 BP 神经网络模型等方法, 上级政府分解指标时则常 用德尔斐法和集合意见法等。

已有测算指标研究成果大都是从下级政府的角度出发，分析以地区经济效益为主的 各项影响因素权重并计算影响指数，然后分配上级政府的总指标。这些方法源于不同的 理论基础而自成体系，缺少方法之间的对比研究，从而难以横向对比各种方法在实践中 的优劣，且基于本地区需求，与实际操作中 “上级政府控制” 不完全相符。在分解指标 时，上级政府理应以运用上述方法测算的指标为基础并综合考量各项因素进行指标分 解, 然而实际分解过程中普遍存在人为因素干扰严重、各方利益主体无序博亦的现象。 综上所述，理论和实践中亟待一种克服上述问题的分解方法。本文在公平与效率思想指 导下，基于 “自下而上” 和 “自上而下” 相结合的思路，以现有方法为基础，引入破产 模型及其解概念，采用多种可比的方法分解新增建设用地指标，并运用有向图博亦方法 对分解结果进行比较分析，以说明各种新方法的特点及适用范围。

\section{1 研究方法}

\section{1 破产模型概述}

当企业因资不抵债而破产时，如何合理地在其债权人之间分配企业的清算资产? 这 就是破产模型的逻辑起点。关于破产模型的研究最早来自犹太经典《塔木德》, 该典籍蕴 含了犹太人平等观和契约观的基本思想，其中两个具有代表性的典故是 “服装争议” 和 “三妾分产”，这种思想体现在破产模型的解概念中 ${ }^{[9]}$ 。

假设企业现有清算资产 $E \in \mathbb{R}_{+}$需在债权人集 $N$ 中进行分配， $N$ 中债权人索赔的总 额大于 $E$ 。记 $|N|=n$, 债权人 $i \in N$ 的债权为 $c_{i} \in \mathbb{R}_{+}$, 债权向量为 $c=\left(c_{1}, c_{2}, \cdots, c_{n}\right)$, 则 这一破产问题可用破产模型 $(N, c, E)$ 来表示 ${ }^{[10]}$ 。记 $N$ 中破产模型的集合为 $\Gamma^{N}$ 。

$\mathrm{O}^{\prime} \mathrm{Neil} 1^{[11]}$ 系统研究了破产模型。关于破产模型的解, 先后提出了随机到达法则 ${ }^{\left[{ }^{[1]}\right.}$ 、限制 均分收益法则 ${ }^{[12]}$ 、比例法则 ${ }^{[12]}$ 、调整比例法则 ${ }^{[13]}$ 、限制均分损失法则 ${ }^{[14]}$ 、让步均分法则 ${ }^{[14]}$ 、 Talmud 法则 ${ }^{[14]}$ 、Piniles 法则 ${ }^{[15]}$ 、限制平等法则 ${ }^{[16}{ }^{10}$ 等。考虑到新增建设用地指标分解通常是 多主体参与分配的行为及实际操作的可行性，本文选择了以下 6 种破产模型解。

\section{2 破产模型的解及其经济意义}

（1）比例法则，简记为 $P$ 。对任意的 $(N, c, E) \in \Gamma^{N}$ 及 $i \in N$,

$$
P_{i}(N, c, E)=\lambda c_{i}
$$

式中: $\sum_{i \in N} \lambda c_{i}=E$ 。

比例法则是实践中最为常见的法则，它根据债权人各自债权份额占总债权的比例来 分配清算资产。

(2) 限制均分收益法则, 简记为 $C E A$ 。对任意的 $(N, c, E) \in \Gamma^{N}$ 和 $i \in N$,

$$
C E A_{i}(N, c, E)=\min \left\{c_{i}, \lambda\right\}
$$

式中: $\sum_{i \in N} \min \left\{c_{i}, \lambda\right\}=E$ 。

限制均分收益法则优先满足债权份额较小的债权人，对于债权份额较大的债权人一 
视同仁地分配份额 $\lambda$ 。可见，这种分配法则充分保护了小债权人的权益。

(3) 限制均分损失法则, 简记为 $C E L$ 。对任意的 $(N, c, E) \in \Gamma^{N}$ 和 $i \in N$,

$$
C E L_{i}(N, c, E)=\max \left\{0, c_{i}-\lambda\right\}
$$

式中: $\sum_{i \in N} \max \left(0, c_{i}-\lambda\right)=E$ 。

限制均分损失法则聚焦于各债权人的损失，要求各债权人损失额度相同，对于债权 额较小的部分债权人分配额为零。可见，该分配法则对债权份额较小的债权人非常不利。

(4) 限制平等法则, 简记为 $C E$ 。对任意的 $(N, c, E) \in \Gamma^{N}$ 和 $i \in N$,

$$
C E_{i}(N, c, E)= \begin{cases}\min \left\{\frac{c_{i}}{2}, \lambda\right\}, & E \leqslant \sum_{i=1}^{n} \frac{c_{i}}{2} \\ \max \left\{\frac{c_{i}}{2}, \min \left\{c_{i}, \lambda\right\}\right\}, & E>\sum_{i=1}^{n} \frac{c_{i}}{2}\end{cases}
$$

式中: $\lambda$ 值由 $\sum_{i \in N} C E_{i}(c, E)=E$ 确定。

当清算资产小于等于债权总额的一半时，债权人分得其债权半额和 $\lambda$ 值的最小值; 当清算资产大于债权总额的一半时，首先确定各债权人债权份额和 $\lambda$ 值的最小值，然后 在各债权人债权半额及其对应的上述最小值之间取最大值, 即各债权人最终分得的额 度。运用限制平等法则时对小债权人非常有利，与运用限制均分损失法则相比，该法则 较少考虑大债权人的权益。

(5) Piniles 法则, 简记为 Pin。对任意的 $(N, c, E) \in \Gamma^{N}$ 和 $i \in N$,

$$
\operatorname{Pin}_{i}(N, c, E)= \begin{cases}\min \left\{\frac{c_{i}}{2}, \lambda\right\}, & E \leqslant \sum_{i=1}^{n} \frac{c_{i}}{2} \\ \frac{c_{i}}{2}+\min \left\{\frac{c_{i}}{2}, \lambda\right\}, & E>\sum_{i=1}^{n} \frac{c_{i}}{2}\end{cases}
$$

式中: 当 $E \leqslant \sum_{i \in N}\left(c_{i} / 2\right)$ 时, $\lambda$ 由 $\sum_{i \in N} \min \left\{c_{i} / 2, \lambda\right\}=E$ 确定; 当 $E>\sum_{i \in N}\left(c_{i} / 2\right)$ 时, $\lambda$ 由 $\sum_{i \in N}\left[c_{i} / 2+\min \left\{c_{i} / 2, \lambda\right\}\right]=E$ 确定。

当清算资产小于等于债权总额一半时，债权人分得其债权半额和 $\lambda$ 值的最小值; 当 清算资产大于债权总额一半时，各债权人首先分得各自债权额的一半，然后分配各债权 人其债权半额和 $\lambda$ 值之间的最小值。可见，运用Piniles 法则时，债权分配结构比较复杂。

（6） Talmud法则，简记为 $T$ 。对任意的 $(N, c, E) \in \Gamma^{N}$ 和 $i \in N$,

$$
T_{i}(N, c, E)= \begin{cases}\min \left\{\frac{c_{i}}{2}, \lambda\right\}, & E \leqslant \sum_{i=1}^{n} \frac{c_{i}}{2} \\ c_{i}-\min \left\{\frac{c_{i}}{2}, \lambda\right\}, & E>\sum_{i=1}^{n} \frac{c_{i}}{2}\end{cases}
$$

式中: 当 $E \leqslant \sum_{i \in N}\left(c_{i} / 2\right)$ 时, $\lambda$ 由 $\sum_{i \in N} \min \left\{c_{i} / 2, \lambda\right\}=E$ 确定; 当 $E>\sum_{i \in N}\left(c_{i} / 2\right)$ 时, $\lambda$ 由 $\sum_{i \in N}\left[c_{i}-\min \left\{c_{i} / 2, \lambda\right\}\right]=E$ 确定。

当清算资产小于等于债权总额的一半时，债权人分得其债权半额和 $\lambda$ 值的最小值; 当清算资产大于债权总额的一半时, 首先确定债权人债权半额和 $\lambda$ 值之间的最小值, 然 后债权人分得其债权额减去该最小值。 


\section{3 基于有向图博栾理论的破产模型解的对比分析}

Brink 等 ${ }^{\left[{ }^{[17}\right]}$ 最早提出了有向图博弯概念。 $N$ 上的有向图可用有序二元组 $(N, D)$ 来表 示，其中 $N$ 表示图的点集合， $D$ 则表示图的边集合，即 $D \subset N \times N$ 是 $N$ 上的二元关系。 记 $N$ 上所有有向图的集合为 $D^{N}$ 。任取 $D \in D^{N}$, 称集合 $S_{D}(i)=\{j \in N \mid(i, j) \in D\}$ 为 $i \in N$ 的 后继集，集合 $P_{D}(i)=\{j \in N \mid(j, i) \in D\}$ 为 $i$ 的前驱集。

对任意的 $(N, D)$ ，其上有向图博弯 $(N, v)$ 是一个效用可转移合作博弯，具体定义 如下:

$$
v_{D}(E)=\left|\left\{j \in S_{D}(E) \mid P_{D}(j) \subset E\right\}\right|
$$

式中: $E \subset N$ 。

对任意的有向图博弯 $(N, v)$ 及 $i \in N$, 其中任意一个点的优势度可定义如下:

$$
\beta_{i}(D)=\sum_{j \in S_{D}(i)} \frac{1}{\left|P_{D}(j)\right|}
$$

本文中，各种破产模型解之间的比较形成了一个有向图 $(N, D)$ ，尽管各种破产模型 的解都有其合理性，但由于算法各异，这里应用有向图博弯方法对破产模型的解进行对 比分析。对上述各种方法的 $\beta$ 值进行排序。根据有向图博弯的原理可知, $\beta$ 值越大, 说 明分配结果越强调效率，反之，则对效率关注程度越小。

\section{2 结果分析}

\section{1 实例介绍}

研究数据来自《苯阳市年土地利用总体规划大纲（2006-2020年）》及相关研究成 果。麥阳市属县级行政单位，位于湖北省西北部，下辖 12 个建制镇、3个街道办和 1 个 开发区。2005 年全市建设用地总面积为 $37677 \mathrm{hm}^{2}$ ，占土地总面积的 11.5\%。1996-2005 年全市建设用地规模变化情况如表 1 所示。以影响束阳市建设用地需求的各项社会经济 指标为基础，运用层次分析法和熵权法确定权重，计算各下属行政区的综合评价值并确 定其分解比例，即可求得全市各行政区新增建设用地指标（表 1） ${ }^{[18]}$ 。

\section{2 新增建设用地需求分析}

以疋阳市历年建设用地规模为基础，如表 2 所示，运用Excel 对 2020 年建设用地需求

表 1 规划中新增建设用地分解指标及比例

Table 1 The quota and proportion of newly-added construction land in the planning

\begin{tabular}{ccc||ccc}
\hline 行政区 & 2020年新增指标 $/ \mathrm{hm}^{2}$ & 比例 $/ \%$ & 行政区 & 2020年新增指标 $/ \mathrm{hm}^{2}$ & 比例 $/ \%$ \\
\hline 北城办 & 298.64 & 13.9 & 新市镇 & 65.94 & 3.1 \\
南城办 & 321.91 & 15.0 & 鹿头镇 & 62.98 & 2.9 \\
环城办 & 146.81 & 6.8 & 刘升镇 & 86.19 & 4.0 \\
开发区 & 211.15 & 9.8 & 兴隆镇 & 122.77 & 5.7 \\
琚湾镇 & 104.59 & 4.9 & 王城镇 & 54.36 & 2.5 \\
七方镇 & 117.51 & 5.5 & 平林镇 & 40.13 & 1.9 \\
杨当镇 & 86.29 & 4.0 & 吴店镇 & 235.63 & 11.0 \\
太平镇 & 108.82 & 5.1 & 熊集镇 & 83.37 & 3.9 \\
& & 合计 & 2147.09 & 100 \\
\hline
\end{tabular}


进行趋势预测，各种分析模型及其相关性指数如表 3 所示。

根据相关性系数值的比较，选择相关性最大的多项式模型：

$$
y=7.6098 x^{2}-3.7386 x+36991
$$

采用式（9）对表 2 的数据进行预测计算，得出 2020 年東阳市建设用地规模为 $41653.66 \mathrm{hm}^{2}$, 扣减现状用地规模，新增建设用地需求总额为 $3976.66 \mathrm{hm}^{2}$ 。结合表 1 中苯 阳市下属 16 个行政区新增建设用地需求额的比例，可计算其需求指标，如表 4 所示。

表 2 1996-2005 年柊阳市建设用地规模

Table 2 The construction land scale of Zaoyang during 1996-2005

$\left(\mathrm{hm}^{2}\right)$

\begin{tabular}{ccccccccccc}
\hline 年份 & 1996 & 1997 & 1998 & 1999 & 2000 & 2001 & 2002 & 2003 & 2004 & 2005 \\
\hline 建设用地面积 & 36950 & 36970 & 37050 & 37410 & 37110 & 37120 & 37080 & 37595 & 37671 & 37677 \\
\hline
\end{tabular}

表 3 建设用地规模发展趋势预测模型

Table 3 The trend forecast models of construction land scale

\begin{tabular}{cccccc}
\hline 类别 & 指数 & 线性 & 对数 & 多项式 & 幂 \\
\hline 模型 & $y=36826 \mathrm{e}^{0.0021 x}$ & $y=79.97 x+36823$ & $y=298.54 \ln x+36812$ & $y=7.6098 x^{2}-3.7386 x+36991$ & $y=36814 x^{0.008}$ \\
相关性 & $R^{2}=0.6799$ & $R^{2}=0.6797$ & $R^{2}=0.5552$ & $R^{2}=0.7191$ & $R^{2}=0.5562$ \\
\hline
\end{tabular}

\section{3 破产模型的应用条件分析}

由于不能完全满足下属行政区新 增建设用地指标需求，可将上级政府 视为一家破产企业，上级政府掌控的 新增建设用地指标为清算资产，下属 行政区为债权人，各下属行政区的新 增建设用地需求量为债权份额。由破 产模型及其解的定义可知, 采用破产 模型解应满足三个条件：一是债权人 债权总额大于可分配的清算资产，此 为破产问题核心内涵要求; 二是各债 权人的债权份额是真实且可比的, 其

\section{表 4 新增建设用地需求指标}

Table 4 The demand of newly-added construction land $\quad\left(\mathrm{hm}^{2}\right)$

\begin{tabular}{cc||cc}
\hline 行政区 & 需求指标 & 行政区 & 需求指标 \\
\hline 南城办 & 596.11 & 琚湾镇 & 194.06 \\
北城办 & 553.01 & 刘升镇 & 159.64 \\
吴店镇 & 437.43 & 杨当镇 & 159.66 \\
开发区 & 390.86 & 熊集镇 & 154.29 \\
环城办 & 271.75 & 新市镇 & 122.08 \\
兴隆镇 & 227.43 & 鹿头镇 & 116.22 \\
七方镇 & 217.52 & 王城镇 & 100.61 \\
太平镇 & 201.62 & 平林镇 & 74.36 \\
& & 合计 & 3976.66 \\
\hline
\end{tabular}

真实可比性直接影响到破产分配结果的合理性; 三是债权人最后分得的份额之和与可分 配清算资产相等，这是破产模型应用的约束条件。

土地利用总体规划编制时各下辖行政区新增建设用地需求之和大于上级政府掌控的 指标总额，这种过度需求现象在实践中普遍存在，其原因在于当前地方政府将土地资源 作为推动经济发展的主要政策工具 ${ }^{[19]}$ 。需求指标之和为 $3976.66 \mathrm{hm}^{2}$, 大于可分解指标总 额 $2147.09 \mathrm{hm}^{2}$, 符合条件一。土地利用总体规划实践中各下辖行政区需求指标通常不符 合真实可比性的要求, 其原因在于各地预测需求时统计口径不一, 且受人为因素干扰。 运用破产模型解时，可要求各下属行政区采用同样的方法预测本地新增建设用地需求， 上级政府对下属行政区的需求指标进行统一审核，以确保其可比性。文献 [18] 运用同样 方法计算了責阳市各下属行政区新增建设用地指标的分解权重，并结合全市新增建设用 地需求总额计算各下属行政区的需求指标，因此，符合条件二。由于各种破产模型及其 
解均隐含相同的约束条件，即债权人分得份额之和与清算资产总额相等，本例的分析过 程和结果亦遵循该项要求，所以符合条件三。综上所述，本例具备破产模型及其解应用 的条件。

\section{4 新增建设用地指标分解计算}

根据式（1） 式（6），运用破产模型的解测算菄阳市新增建设用地指标，分别求得 麥阳市各下属行政区的 6 种分解结果，如表 5 所示。以表 5 的数据为基础，根据式（8）, 运用有向图博弯方法对破产模型解进行评价，求得各种方法的 $\beta$ 值，如表 6 所示，其中 满足程度通过各行政区各种破产分配结果占相应需求指标的比例来衡量。

\section{5 新增建设用地指标分解结果分析}

比例法则是使用最为普遍的法则，文献 [18] 中最后进行指标分配时采用的就是比例 法则。根据 $\mathrm{Adams}^{[20]}$ 的公平理论可知，比例法则是最为公平的分配方法。采用比例法则 时，各行政区指标的满足程度相同。本例中满足程度均为 $54 \%$ 。

采用限制均分收益法则时，需求指标较小的行政区得到了完全的满足，需求指标较 大的行政区则平均分配了剩余的指标。该种方法虽然充分保护了建设用地指标规模较小 的行政区，但在规模较大的行政区分配时显得有些粗鉌。运用限制平等法则时，建设用 地指标需求规模越小的行政区得到满足的程度越高，但需求中等规模以上的行政区均满

\section{表 5 基于破产模型的新增建设用地指标分解结果}

Table 5 The allocation scenarios of newly-added construction land based on bankruptcy model

\begin{tabular}{|c|c|c|c|c|c|c|c|c|c|c|c|c|}
\hline \multirow[b]{2}{*}{ 行政区 } & \multicolumn{2}{|c|}{$P_{i}(N, c, E)$} & \multicolumn{2}{|c|}{$C E A_{i}(N, c, E)$} & \multicolumn{2}{|c|}{$C E L_{i}(N, c, E)$} & \multicolumn{2}{|c|}{$C E_{i}(N, c, E)$} & \multicolumn{2}{|c|}{$\operatorname{Pin}_{i}(N, c, E)$} & \multicolumn{2}{|c|}{$T_{i}(N, c, E)$} \\
\hline & $\begin{array}{l}\text { 指标 } \\
/ \mathrm{hm}^{2}\end{array}$ & $\begin{array}{c}\text { 比例 } \\
1 \% \\
\end{array}$ & $\begin{array}{l}\text { 指标 } \\
/ \mathrm{hm}^{2} \\
\end{array}$ & $\begin{array}{c}\text { 比例 } \\
/ \% \\
\end{array}$ & $\begin{array}{l}\text { 指标 } \\
/ \mathrm{hm}^{2}\end{array}$ & $\begin{array}{c}\text { 比例 } \\
1 \% \\
\end{array}$ & $\begin{array}{l}\text { 指标 } \\
/ \mathrm{hm}^{2}\end{array}$ & $\begin{array}{c}\text { 比例 } \\
/ \% \\
\end{array}$ & $\begin{array}{l}\text { 指标 } \\
/ \mathrm{hm}^{2}\end{array}$ & $\begin{array}{c}\text { 比例 } \\
1 \% \\
\end{array}$ & $\begin{array}{l}\text { 指标 } \\
/ \mathrm{hm}^{2}\end{array}$ & $\begin{array}{c}\text { 比例 } \\
1 \% \\
\end{array}$ \\
\hline 南城办 & 321.91 & 54 & 144.48 & 24 & 477.77 & 80 & 298.06 & 50 & 307.98 & 52 & 384.61 & 65 \\
\hline 北城办 & 298.64 & 54 & 144.48 & 26 & 434.67 & 79 & 276.51 & 50 & 286.43 & 52 & 341.51 & 62 \\
\hline 吴店镇 & 235.63 & 54 & 144.48 & 33 & 319.10 & 73 & 218.72 & 50 & 228.64 & 52 & 225.93 & 52 \\
\hline 开发区 & 211.15 & 54 & 144.48 & 37 & 272.52 & 70 & 195.43 & 50 & 205.35 & 53 & 195.43 & 50 \\
\hline 环城办 & 146.81 & 54 & 144.48 & 53 & 153.41 & 56 & 135.87 & 50 & 145.80 & 54 & 135.87 & 50 \\
\hline 兴隆镇 & 122.77 & 54 & 144.48 & 64 & 109.09 & 48 & 113.72 & 50 & 123.64 & 54 & 113.72 & 50 \\
\hline 七方镇 & 117.51 & 54 & 144.48 & 66 & 99.18 & 46 & 108.76 & 50 & 118.68 & 55 & 108.76 & 50 \\
\hline 太平镇 & 108.82 & 54 & 144.48 & 72 & 83.28 & 41 & 100.81 & 50 & 110.73 & 55 & 100.81 & 50 \\
\hline 琚湾镇 & 104.59 & 54 & 144.48 & 74 & 75.72 & 39 & 97.03 & 50 & 106.95 & 55 & 97.03 & 50 \\
\hline 刘升镇 & 86.19 & 54 & 144.48 & 91 & 41.31 & 26 & 87.97 & 55 & 89.74 & 56 & 79.82 & 50 \\
\hline 杨当镇 & 86.29 & 54 & 144.48 & 90 & 41.33 & 26 & 87.97 & 55 & 89.75 & 56 & 79.83 & 50 \\
\hline 熊集镇 & 83.37 & 54 & 144.48 & 94 & 35.96 & 23 & 87.97 & 57 & 87.07 & 56 & 77.15 & 50 \\
\hline 新市镇 & 65.94 & 54 & 122.08 & 100 & 3.75 & 3 & 87.97 & 72 & 70.96 & 58 & 61.04 & 50 \\
\hline 鹿头镇 & 62.98 & 54 & 116.22 & 100 & 0 & 0 & 87.97 & 76 & 68.03 & 59 & 58.11 & 50 \\
\hline 王城镇 & 54.36 & 54 & 100.61 & 100 & 0 & 0 & 87.97 & 87 & 60.23 & 60 & 50.30 & 50 \\
\hline 平林镇 & 40.13 & 54 & 74.36 & 100 & 0 & 0 & 74.36 & 100 & 47.10 & 63 & 37.18 & 50 \\
\hline
\end{tabular}

表 6 新增建设用地指标破产模型解的 $\beta$ 值

Table 6 The $\beta$ value of solution to bankruptcy model of quota of newly-added construction land

\begin{tabular}{ccccccc}
\hline 法则 & $P$ & $C E A$ & $C E L$ & $C E$ & $P$ Pin & $T$ \\
\hline$\beta$ 值 & 4.43 & 6.20 & 11.83 & 6.50 & 3.87 & 7.73 \\
\hline
\end{tabular}


足半额需求。

由于参与者的行为选择由夏普利值决定 ${ }^{[21]}$, 结合有向图博弯原理可知, $\beta$ 值最大符 合效率最优的选择。限制均分损失法则的 $\beta$ 值最大, 运用该方法分解指标时, 需求指标 较小的部分行政区给予较少的指标，甚至为零，需求指标较大的部分行政区则会得到较 大程度的满足。Talmud 法则 $\beta$ 值仅小于均分损失法则, 采用 Talmud法则时, 需求指标较 小的部分行政区满足半额需求, 需求指标较大的部分行政区需求额度由小到大, 满足程 度呈上升状态。可见，Talmud法则在重点关注效率的同时兼顾了需求指标较小行政区公 平的要求。相应地，由于 Piniles 法则的 $\beta$ 值最小，该种方法最不符合效率优先的要求。

\section{3 结论}

如何在新增建设用地指标分解时处理公平与效率的关系，反映了地区发展的不同主 张和策略。“效率优先” 主张与非均衡发展策略相对应, “公平优先” 主张与均衡发展策 略相对应 ${ }^{[2]}$, 不同的发展阶段和地区应该选择不同的发展策略。叶浩等 ${ }^{[23]}$ 、李鹏等 ${ }^{[24]}$ 分别 以全国和江苏省为对象探讨建设用地指标需求与地区经济发展之间的关系，实证分析表 明两者之间存在高度的相关性。因而本文总结分析时认为, 建设用地指标需求多的地区 经济发展水平高。基于以上分析，研究结论如下:

（1）在经济相对发达的发展阶段和地区，按照“公平优先”的要求采用均衡发展策 略，可结合土地利用总体规划编制实践采用比例法则或Piniles 法则，即在新增建设用地 指标分解时按照各地区需求同等程度的分解指标。

（2）在经济相对落后的发展阶段和地区，按照 “效率优先” 的要求采用非均衡发展 策略，可结合土地利用总体规划编制实践采用限制均分损失法则或 Talmud法则，即经济 效率较高的地区在新增建设用地指标分解时尽量满足其需求, 经济效率较低的地区则扣 减其需求。

（3）在其他情形下，可根据实际需要采取不同的方法。比如在当前国家扶贫大战略 背景下，对于区域内具备发展条件的贫困地区，可结合土地利用总体规划编制实践采用 限制平等法则或限制均分收益法则，即优先满足贫困地区对新增建设用地指标的需求， 再适当考虑其他地区的需求。

\section{参考文献(References):}

[1] 靳相木, 姚先国. 农地非农化管理的分权取向改革及其情景模拟. 公共管理学报, 2010, 7(3): 10-20. [JIN X M, YAO X G. The decentralization reform and the situation simulation of agricultural land non-agricultural management. Journal of Public Management, 2010, 7(3): 10-20.]

[2] TAN R, ZHOU T X. Decentralization in a centralized system: Project-based governance for land-related public goods provision in China. Land Use Policy, 2015, 47: 262-272.

[3] 刘瑞卿, 朱伟亚, 许暞. 基于主体功能区的土地规划新增建设用地指标调控研究: 以河北省卢龙县为例. 中国生态农 业学报, 2012, 20(4): 507-512. [LIU R Q, ZHU W Y, XU H. Study on new construction land regulation in land use planning based on major function-oriented zoning: A case study of Lulong county, Hebei province. Chinese Journal of EcoAgriculture, 2012, 20(4): 507-512.]

[4] 靳相木, 沈子龙. 新增建设用地管理的“配额一交易”模型: 与排污权交易制度的对比研究. 中国人口・资源与环境, 2010, 20(7): 86-91. [JIN X M, SHEN Z L. The cap-and-trade model of incremental construction land quota: An analog with the emission permits system. China Population, Resources and Environment, 2010, 20(7): 86-91.]

[5] 殷少美, 金晓斌, 周寅康, 等. 基于主成分分析法和AHP-GEM模型的区域新增建设用地指标合理配置: 以江苏省为 
例. 自然资源学报, 2007, 22(3): 372-379. [YIN S M, JIN X B, ZHOU Y K, et al. Allocation of newly-added quota of regional construction land based on principal components analysis and AHP-GEM model: A case study of Jiangsu province. Journal of Natural Resources, 2007, 22(3): 372-379.]

[6] 翟腾腾, 郭杰, 欧名豪, 等. 基于基尼系数的江苏省建设用地总量分配研究. 中国人口·资源与环境, 2015, 25(4): 8491. [ZHAI T T, GUO J, OU M H, et al. Study on allocation of total construction land in Jiangsu province based on the Gini coefficient. China Population, Resources and Environment, 2015, 25(4): 84-91.]

[7] 洪建国, 杨钢桥, 苗欣, 等. 增量城镇用地区域配置研究: 以湖北省为例. 中国土地科学, 2008, 22(12): 39-45. [HONG J G, YANG G Q, MIAO X, et al. Study on regional allocation of newly increased construction land of urban and town: A case of Hubei province. China Land Science, 2008, 22(12): 39-45.]

[8] 刘耀林, 国洪艳, 唐旭, 等. 网络参与式土地利用规划决策博亦研究. 中国土地科学, 2011, 25(9): 22-27. [LIU Y L, GUO H Y, TANG X, et al. Game theoretical analysis on the decision process of land use planning of the web-based-participation pattern. China Land Science, 2011, 25(9): 22-27.]

[9] THOMSON W. Axiomatic and game-theoretic analysis of bankruptcy and taxation problems: A survey. Mathematical Social Sciences, 2003, 45(3): 249-297.

[10] 李登峰, 胡勋锋. 带层次结构效用可转移合作对策的 $\tau$ 值. 系统工程学报, 2017, 37(2): 177-187. [LI D F, HU X F. $\tau$ value of transferable utility cooperative games with level structures. Journal of Systems Engineering, 2017, $37(2)$ : 177187.]

[11] O'Neill B. A problem of rights arbitration from the Talmud. Mathematical Social Sciences, 1980, 2(4): 345-371.

[12] THOMSON W. Axiomatic and game-theoretic analysis of bankruptcy and taxation problems: A survey. Mathematical Social Sciences, 2003, 45(3): 249-297.

[13] CURIEL I J, MASCHLER M, TIJS S H. Bankruptcy games. Zeitschrift Für Operations Research, 1987, 31(5): A143A159.

[14] AUMANN R J, MASCHLER M. Game theoretic analysis of a bankruptcy problem from the Talmud. Journal of Economic Theory, 1985, 36(2): 195-213.

[15] PINILES H M. Darkah Shel Torah. Forester, Vienna, 1861.

[16] CHUN Y, THOMSON W, SCHUMMER J. Constrained Egalitarianism: A new solution to bankruptcy problems. Seoul Journal of Economics, 2001, 14: 269-297.

[17] BRINK R V D, BORM P. Digraph competitions and cooperative games. Theory \& Decision, 2002, 53(4): $327-342$.

[18] 杜金龙, 马才学. 县级土地利用总体规划中净增建设用地指标分解: 以湖北省莕阳市为例. 国土资源科技管理, 2010, 27(2): 98-103. [DU J L, MA C X. Quota distribution of net increased construction land in county-level general planning of land use: A case study of Zaoyang city, Hubei province. Scientific and Technological Management of Land and Resources, 2010, 27(2): 98-103.]

[19] 陶然, 汪晖. 中国尚未完成之转型中的土地制度改革: 挑战与出路. 国际经济评论, 2010, 33(2): 93-123. [TAO R, WANG H. China's unfinished land system reform: Challenges and solutions. Review of International Economics, 2010, 33(2): 93-123.]

[20] ADAMS J S. Inequity in social exchange. Advances in Experimental Social Psychology, 1965, 2(4): 267-299.

[21] 高政利, 梁工谦. 论经济组织、权力结构与制度的制序度: 不同利益参与者行为选择的夏普利值分析. 财经研究, 2008, 34(3): 107-120. [GAO Z L, LIANG G Q. Economic organization, power structure and the degree of system order: Shapley analysis on different beneficiary's behavior choice. Journal of Finance and Economics, 2008, 34(3): 107-120.]

[22] 孙斌栋, 郑燕. 我国区域发展战略的回顾、评价与启示. 人文地理, 2014, 29(5): 1-7. [SUN B D, ZHENG Y. Review, evaluation and inspiration of regional development strategies in China. Human Geography, 2014, 29(5): 1-7.]

[23] 叶浩, 张鹏, 誉励杰. 中国建设用地与区域社会经济发展关系的空间计量研究. 地理科学, 2012, 32(2): 149-155. [YE H, ZHANG P, PU L J. Spatial econometrics study of relationship between regional socio-economic development and construction land in China. Scientia Geographica Sinica, 2012, 32(2): 149-155.]

[24] 李鹏, 誉励杰. 发达地区建设用地扩张与经济发展相关关系的探究: 基于与全国平均水平的比较. 自然资源学报, 2012, 27(11): 1823-1832. [LI P, PU L J. Delving into the particularity on the relationship between construction land expansion and economic growth in developed region: Comparing with the average of the whole China. Journal of Natural Resources, 2012, 27(11): 1823-1832.] 


\title{
The quota allocation method of newly-added construction land based on the bankruptcy model: A case study of Zaoyang city, Hubei province
}

\author{
ZUO Wen-jin ${ }^{1,2}$, HU Xun-feng ${ }^{3}$, LI Deng-feng ${ }^{1}$ \\ (1. School of Economics and Management, Fuzhou University, Fujian 350108, China; 2. Zhejiang College, \\ Shanghai University of Finance and Economics, Jinhua 321013, Zhejiang, China; 3. School of Management, \\ Guangzhou University, Guangzhou 510006, China)
}

\begin{abstract}
The traditional methods for allocating the quota of newly-added construction land have many deficiencies. For example, the research perspective is single and the administrative force intervened severely. This paper, based on the idea of fairness and efficiency, uses some rules of solution to bankruptcy model to allocate the quota of newly-added construction land in Zaoyang city of Hubei province, and applies digraph game theory to compare various results of the allocation creatively. The basic data of the case analysis come from "The Outline of the General Land Use Planning in Zaoyang city (2006-2020)" and its related research papers. First of all, the total demand for newly-added construction land in the whole city in 2020 is predicted to be $3976.66 \mathrm{hm}^{2}$ by using the polynomial model that is based on the data of the construction land during 1996-2005. Secondly, the requirements of 16 subordinate administrative districts were determined by the analytic hierarchy process and entropy weight method, and then, a total of $2147.09 \mathrm{hm}^{2}$ of newly-added construction land was decomposed among the subordinate districts by six rules of solution to bankruptcy model. Finally, the characteristics of various allocated schemes are analyzed according to the digraph game method. The concept corresponding to fairness and efficiency is balanced development and unbalanced development. Different stages and regions may follow different development ideas in practice of the general land use planning. The research results show that: (1) The proportional rule and the Piniles rule accord with the proposition of "fairness priority", which is applicable to the balanced development strategy in the development stage and region of relatively developed economy; (2) The constrained equal losses rule and the Talmud rule accord with the idea of "efficiency priority", which is applicable to the unbalanced development strategy in the development stage and region of relatively backward economy; (3) The constrained equal awards rule and the constrained egalitarian rule are applicable to the key support strategy in poverty-stricken areas. The new method not only avoids the problems caused by traditional methods, but also provides some choices for regional development strategy. The new method proposed in this paper can not only be used in new round of the general land use planning, but also be widely used in the distribution of public resources.
\end{abstract}

Keywords: bankruptcy model; digraph game; newly-added construction land; quota allocation; Zaoyang 